\title{
SISTEM PENDUKUNG KEPUTUSAN UNTUK TANAMAN HORTIKULTURA DENGAN METODE DESAIN SPRINT
}

\author{
Trismayanti Dwi Puspitasari1 ${ }^{\# 1}$, Nanik Anita ${ }^{* 2}$ \\ \#*Jurusan Teknologi Informasi, Politeknik Negeri Jember \\ Mastrip POBOX 164 Jember \\ 1trismayanti@polije.ac.id \\ 2anita07nur@gmail.com
}

\begin{abstract}
The selection of plants to be planted is not easy for people who are unfamiliar with knowledge of horticulture, so an application is needed to develop with a decision support system that can help decide which plants are planted according to the $\mathrm{pH}$, temperature, rainfall and height of land. The development methodology that will be used is the sprint design. The design sprint is very suitable for projects that require fast time to get a solution because it is a shortcut that can be used before creating and launching a product, so that it can cut the required budget. The aim of this research are made prototype system that able to provide information about the types of plants using design sprint method.
\end{abstract}

Keywords - decision support system, design sprint, horticulture, prototype.

\section{Pendahuluan}

Jember merupakan Kabupaten dengan jumlah penduduk tertinggi ketiga setelah kota Surabaya dan Malang yaitu 2.407.115 jiwa dari 38 Kabupaten/Kota. Jumlah penduduk yang tinggi tidak menjamin untuk angka harapan hidup yang tinggi pula karena Jember merupakan Kabupaten dengan indeks terendah ke-2 di Jawa Timur dengan 63,64 tahun. Faktor yang mendasari ini adalah tingkat kemiskinan mencapai $11,2 \%$ dari jumlah penduduk yang ada [1].

Di Kabupaten Jember, sulit untuk menambah jumlah lahan pertanian dan menekan laju penduduk, namun yang perlu ditindaklanjuti yaitu strategi dalam menyelesaikan ketahanan pangan pada lahan yang ada. Di Kabupaten Jember berbagai jenis tanaman holtikultura bisa ditemui dan dikembangkan masyarakat. Namun, potensi yang dimiliki, belum sepenuhnya bisa memberikan kontribusi besar terhadap upaya peningkatan ketahanan pangan. Temuan utama di Kabupaten Jember khususnya Faktor iklim dan lingkungan yang mempengaruhi ketahanan pangan. Perubahan iklim memiliki potensi dampak yang besar terhadap ketahanan pangan di Provinsi Jawa Timur. Bencana alam dan perubahan iklim memiliki potensi dampak yang besar terhadap ketahanan pangan di Provinsi Jawa Timur. Terjadinya kejadian iklim ekstrim yang menyebabkan hilangnya produksi tanaman pangan dalam jumlah yang signifikan sebagian besar berkaitan dengan fenomena El Niño / Southern Oscillation (ENSO). Peningkatan suhu permukaan laut sebesar satu derajat celcius memiliki dampak negatif yang signifikan terhadap curah hujan di Kabupaten Probolinggo, Lumajang, Jember, Bondowoso, Banyuwangi dan Kota Batu [2].

Ketahanan pangan telah meningkat untuk sebagian besar masyarakat Provinsi Jawa Timur antara tahun 2010 dan 2015, terutama sebagai akibat dari perbaikan pada beberapa indikator ketahanan pangan dan gizi. Namun kemajuan tersebut dapat mengalami hambatan jika tantangan-tantangan utama yang ada tidak ditangani dengan baik. Salah satunya adalah mengatasi kerentanan terhadap resiko perubahan iklim yang semakin meningkat. Perubahan iklim tetap menjadi ancaman besar bagi ketahanan pangan, terutama bagi rumah tangga yang mata pencahariannya bergantung pada sektor pertanian. Peningkatan iklim secara drastis, deviasi curah hujan, peningkatan frekuensi dan intensitas perubahan iklim, peningkatan resiko hama tanaman yang berdampak negative. Hal ini berdampak pada rendahnya produksi dan produktifitas tanaman, yang pada akhirnya akan mengganggu mata pencaharian petani secara keseluruhan.

Salah satu upaya dalam meningkatkan ketahanan pangan salah satunya dapat dilakukan dengan budidaya tanaman holtikultura. Budidaya holtikultura dapat memberikan manfaat langsung dengan dikonsumsi 
pribadi maupun dijual, karena cara menanam yang dapat dilakukan di pekarangan rumah atau kebun. Akan tetapi usaha dalam pembudidayaan sering mengalami hambatan. Hambatan itu adalah kurangnya pengetahuan dan pemahaman penanam dalam menentukan jenis tanaman holtikultura terhadap kondisi wilayah baik lahan maupun perubahan iklim yang sering terjadi.

Menyikapi masalah diatas maka perlu dilakukan penelitian mengenai "Sistem Pendukung Keputusan Untuk Tanaman Hortikultura Dengan Metode Desain Sprint " dengan harapan mampu meningkatkan angka harapan hidup dan mampu mengurangi tingkat kemiskinan di Kabupaten Jember. Sistem Pendukung Keputusan (SPK) digunakan untuk mencari alternatif optimal dari sejumlah alternatif keputusan. Design Sprint merupakan kerangka yang dibuat berdasarkan Design Thinking. Design Thinking yang dimaksud merupakan kerangka kerja yang dilakukan dalam waktu lima hari dimana setiap anggota dalam tim akan berdiskusi sehingga dapat menghasilkan gagasan/ide masing-masing yang kemudian akan digunakan untuk menyelesaikan permasalahan yang ada. Metodelogi ini dilakukan untuk menjawab pertanyaan-pertanyaan dari calon pengguna dengan membuat desain, menciptakan prototype (bentukan awal, atau model sederhana yang mengijinkan calon pengguna memiliki gambaran dasar), dan menguji ide. Design sprint sangat cocok digunakan pada proyek yang membutuhkan waktu cepat untuk mendapatkan solusi karena metode ini merupakan cara pintas yang dapat digunakan sebelum membuat dan meluncurkan sebuah produk, sehingga dapat memotong anggaran dana yang dibutuhkan juga. Keluaran dari sistem ini mampu memberikan informasi mengenai jenis tanaman yang sesuai sehingga dapat meningkatkan produktivitas dan ketahanan pangan serta memudahkan Dinas pertanian dalam melakukan pengawasan dan pembinaan karena penelitian ini mampu memetakan sentra atas tanaman holtikultura di Kabupaten Jember.

\section{TinJaUAN PUSTAKa}

Sistem pendukung keputusan dimaksudkan untuk menjadi alat bantu bagi para pengambil keputusan untuk memperluas kapabilitas, namun tidak untuk menggantikan penilaian pimpinan[3]. Sistem pendukung keputusan merupakan sistem berbasis komputer interaktif yang membantu pengambil keputusan memanfaatkan data dan model untuk menyelesaikan masalah-masalah yang tak terstruktur. Selain itu, alasan lain dalam pengembangan Sistem pendukung Keputusan adalah perubahan perilaku komputasi end-user,end-user bukanlah programmer, sehingga mereka membutuhkan alat dan prosedur yang mudah untuk digunakan. Proses-proses yang terjadi pada kerangka kerja Sistem Pendukung Keputusan dibedakan atas: terstruktur, tak terstruktur, semi terstruktur.

Design sprint sangat cocok digunakan pada proyek yang membutuhkan waktu cepat untuk mendapatkan solusi karena metode ini merupakan cara pintas yang dapat digunakan sebelum membuat dan meluncurkan sebuah produk, sehingga dapat memotong anggaran dana yang dibutuhkan juga. Metodelogi ini dipimpin oleh seseorang yang disebut sebagai Sprint Master yang bertugas untuk memimpin diskusi, mendefinisikan masalah dan mengambil keputusan terhadap gagasan yang diberikan oleh setiap individu dalam tim. Selain sprint master untuk bisa mengembangkan metodologi dibutuhkan komitmen anggota tim agar selama proses berlangsung fokus pada tahapan design sprint yang akan kita lakukan. Tahapan design sprint yaitu understanding, diverge, decide, prototype, dan validate.

\section{Metode Penelitian}

Tahapan penelitian yang akan diterapkan pada penelitian ini meliputi: proses understanding dengan melakukan wawancara pada pihak terkait yaitu dinas Pertanian mengenai tanaman holikultura dan melakukan pencarian data pada BPS; diverge yaitu proses pembuatan sketsa mock up; decide mendiskusikan hasil sketsa mock up dengan anggota tim untuk persiapan proses selanjutnya yaitu pembuatan prototype; prototype dibuat dengan menggunakan google doc presentation; dan validate proses memvalidasi kembali hasil prototype kepada calon pengguna aplikasi.

\section{Hasil Dan PEMbahasan}

Pada tahapan understanding di dapatkan data - data dari pihak terkait: variabel penelitian terlihat dalam proses input dari rancangan sistem penelitian terdapat pada Gambar 1 yaitu data yang terikat tentang syarat tumbuh tanaman holtikultura. Variabel penelitian didapatkan dari data Dinas Pertanian Kabupaten Jember tabel 1 dan table 2 
Jurnal Teknologi Informatika dan Terapan Vol. 05, No 02, Juli - Desember 2018 ISSN: 2354-838X

TABEL II

Data Range Semesta Pembicaraan

\begin{tabular}{|l|l|l|}
\hline Variabel & Himpunan & Domain \\
\hline PH & Rendah & {$[0-7]$} \\
& Sedang & {$[6,5-8,5]$} \\
& Tinggi & {$[7-14]$} \\
\hline Suhu & Rendah & {$[0-20]$} \\
& Sedang & {$[20-27]$} \\
& Tinggi & {$[>25]$} \\
\hline Curah Hujan & Rendah & {$[0-350]$} \\
& Sedang & {$[350-500]$} \\
& Tinggi & {$[>500]$} \\
\hline Ketinggian Tanah & Rendah & {$[0-200]$} \\
& Sedang & {$[200-750]$} \\
& Tinggi & {$[>700]$} \\
\hline
\end{tabular}

TABEL IIII

SYARAT TUMBUH TANAMAN

\begin{tabular}{|c|c|c|c|c|}
\hline Nama & PH & SUHU & $\begin{array}{c}\text { CURAH } \\
\text { HUJAN } \\
\text { (MM/ } \\
\text { Tahun) } \\
\end{array}$ & $\begin{array}{c}\text { KETINGGIAN } \\
\text { TANAH } \\
(\mathrm{M} \text { dpl })\end{array}$ \\
\hline $\begin{array}{l}\text { Bawang } \\
\text { Merah } \\
\text { Bawang }\end{array}$ & $5,5-6,5$ & $27-32$ & $300-2500$ & $0-900$ \\
\hline Daun & $6,7-7,0$ & $15-20$ & $1200-2400$ & $0-700$ \\
\hline Kubis & $6,0-7,0$ & $18-30$ & 1500 & $0-700$ \\
\hline Bayam & $5,5-6,5$ & $16-20$ & 1500 & $0-2000$ \\
\hline $\begin{array}{l}\text { Sawi } \\
\text { Kacang }\end{array}$ & $6,0-7,0$ & $27-32$ & $1000-1500$ & $0-500$ \\
\hline $\begin{array}{l}\text { Panjang } \\
\text { Cabe }\end{array}$ & $5,5-6,5$ & $25-30$ & $700-1500$ & $0-800$ \\
\hline $\begin{array}{l}\text { besar } \\
\text { Cabe }\end{array}$ & $5,0-6,0$ & $24-28$ & $1650-2500$ & $0-1300$ \\
\hline Rawit & $6,0-6,9$ & $18-30$ & $600-1250$ & $0-500$ \\
\hline Terong & $6,0-6,5$ & $25-30$ & $900-1000$ & $0-1000$ \\
\hline Tomat & $5,5-6,8$ & $25-28$ & $650-1250$ & $0-1250$ \\
\hline Buncis & $5,0-6,0$ & $20-25$ & $1700-2500$ & $1000-1500$ \\
\hline $\begin{array}{l}\text { Ketimun } \\
\text { Labu }\end{array}$ & $5,0-6,8$ & $21-30$ & $800-1000$ & $0-900$ \\
\hline Siam & $\begin{array}{c}5,0-6,0 \\
6,0-\end{array}$ & $21-28$ & $1000-1200$ & $0-1100$ \\
\hline Kangkung & 6,9 & 28 & $500-5000$ & 2000 \\
\hline
\end{tabular}

DOI: https://doi.org/10.25047/jtit.v5i2.83
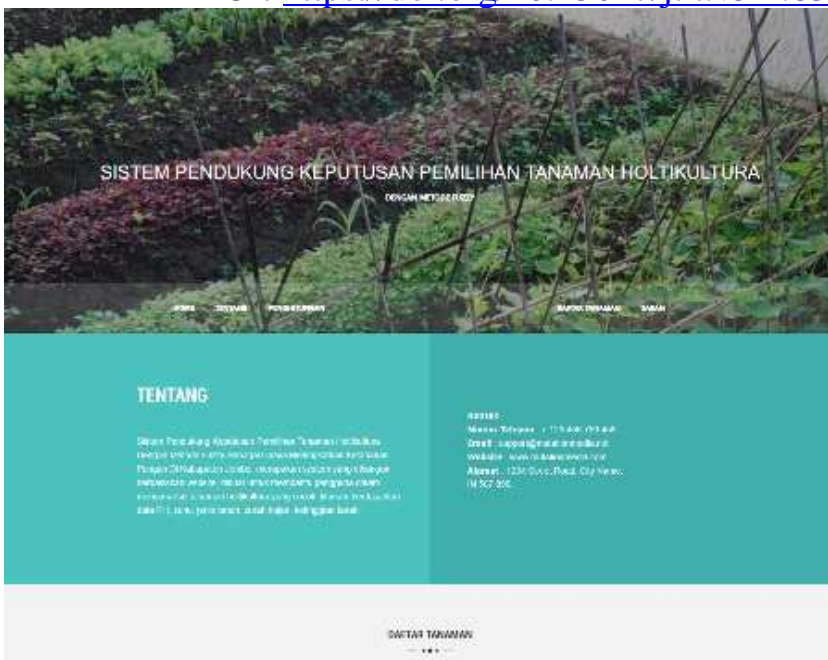

Gambar 2. Beranda
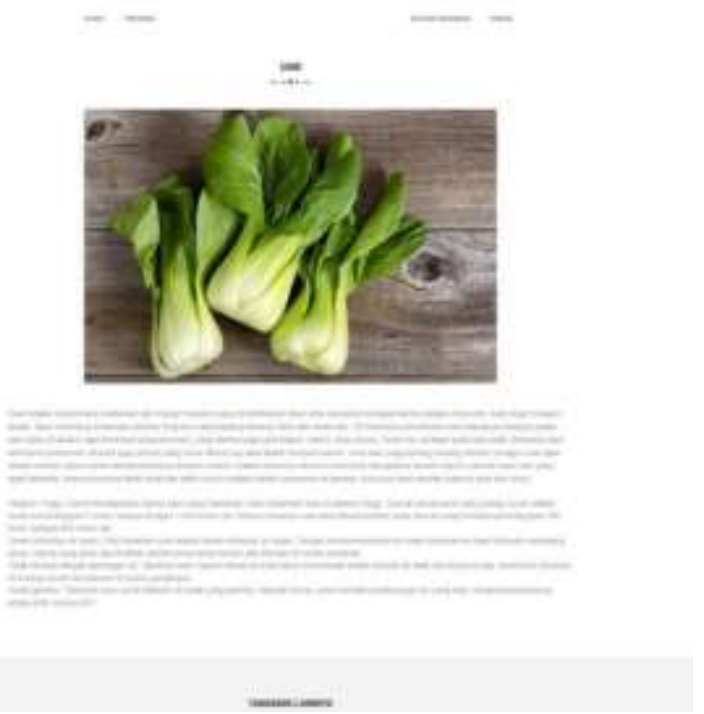

Gambar 3. Informasi

Tahapan diverge dengan pembuatan sketsa tertulis pada Gambar 1

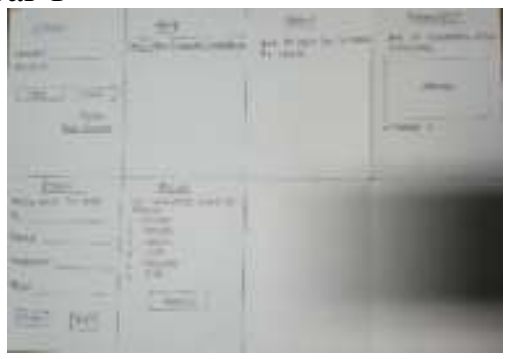

Gambar 1. Sketsa

Gambar 4. Analisis

Tahapan prototyping di google doc presentation adalah sebagai berikut 


\section{Sistem Pendukung Keputusan Untuk Tanaman Hortikultura}

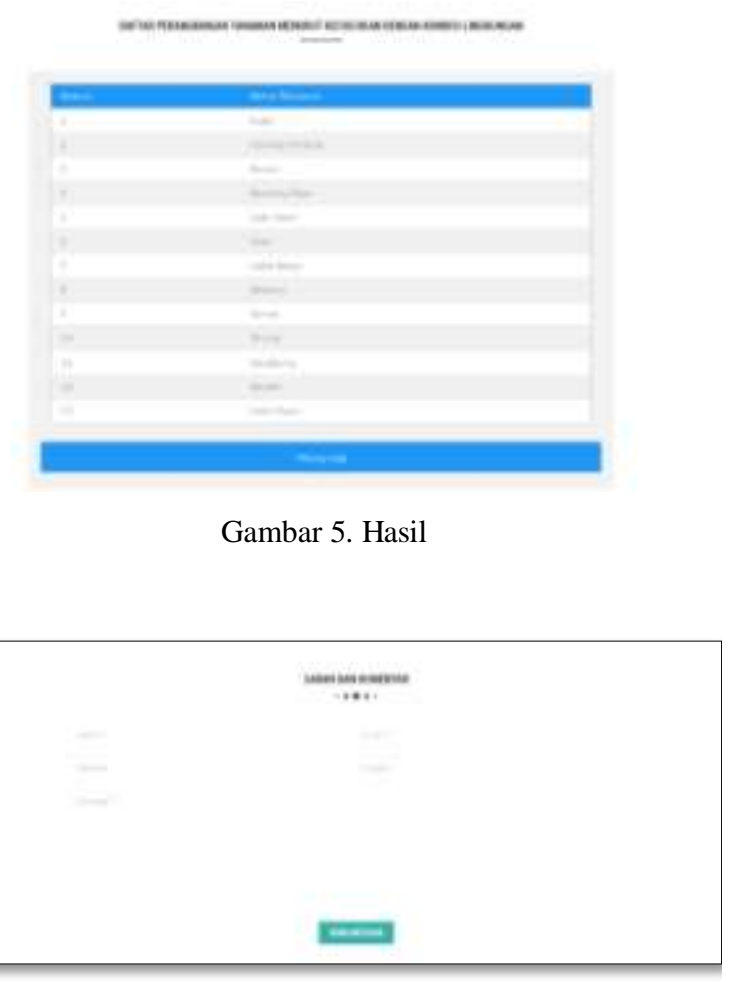

Gambar 6. Saran dan Komentar

Tahapan validate dilakukan kepada calon pengguna dan menyatakan bahwa prototype yang telah dikembangkan sudah sesuai dengan harapan pengguna, sehingga pada tahapan ini tidak ada perbaikan, dan bisa dilanjutkan untuk proses pengembangan pemrograman.

\section{KESIMPULAN}

Keluaran dari penelitian ini adalah prototype untuk menyelesaikan penelitian berikutnya mengenai pembuatan system pendukung keputusan tanaman hortikultura. Penggunaan metode desain sprint untuk mempercepat proses pembuatan dan validasi dengan calon pengguna.

\section{UCAPAN TERIMA KASIH}

Tim penelitian menyampaikan ucapan terima kasih atas pendanaan penelitian Dosen Pemula DRPM Dikti tahun 2017.

\section{DAFTAR PUSTAKa}

[1] BPS. Jawa Timur Dalam Angka. Jawa Timur: BPS Jawa Timur. 2015:80.

[2] Badan Ketahanan Pangan Jawa Timur dan World Food Programme. Peta Ketahanan dan Kerentanan Pangan 2015. Jawa Timur: Badan Ketahanan Pangan Jawa Timur dan World Food Programme. 2015: 23.
[3] Kusumadewi, S dan Purnomo, H. 2010. Aplikasi Logika Fuzzy Untuk Pendukung Keputusan (Edisi 2).

Yogyakarta : Graha Ilmu.

Knapp, Jake. 2017. Sprint: How to Solve Big Problems and Test New Ideas in Just Five Days. Bintang Pustaka 